\title{
PENSAMIENTO ECONÓMICO EN LA TRADICIÓN JUDÍA, CON ESPECIAL REFERENCIA A MOISÉS BEN MAIMÓNIDES: LA PERSPECTIVA AUSTRIACA
}

\author{
ABIE GRYNSPAN GURFINKIEL*
}

Fecha de recepción: 23 de junio de 2016

Fecha de aceptación: 26 de febrero de 2017

Resumen: A pesar de no existir un tratado que englobe un pensamiento económico, la tradición judía, a través de textos legales y religiosos, aborda temas económicos de naturaleza muy variada. Desde tiempos bíblicos se fueron formando el derecho judío y la doctrina moral judía, que regulaban la actividad económica y la vida social en general. Estos fueron evolucionando, y ya para el siglo XII, Moisés ben Maimónides, interpretando y documentando las leyes orales de la tradición judía, con influencia aristotélica y de lbn Bayya, entre otros filósofos; había desarrollado una filosofía moral individualista, subjetivista y racionalista; explorando temas como la teoría del valor subjetivo, la paradoja del valor, la acción humana, los límites de la razón, la cooperación social y división del trabajo.

En el presente artículo se investiga, desde una perspectiva austriaca, el pensamiento económico que contiene la tradición judía, y su posible impacto en el surgimiento del sistema capitalista y la civilización moderna. Asimismo, se estudia la influencia que tuvo la tradición judía y la filosofía de Maimónides, en las doctrinas de Santo Tomás de Aquino; las cuales, tomadas y enriquecidas por los escolásticos de Salamanca, son de acuerdo a algunos pensadores, el tronco de la Escuela Austriaca de Economía.

Palabras clave: capitalismo, escolástica, judaísmo, laissez-faire.

Clasificación JEL: A13, B11, N01, Z12.

* Licenciado en Dirección de Empresas (Universidad de Costa Rica), Máster en Marketing Management (Erasmus University, Rotterdam) y Máster en Economía de la Escuela Austriaca (Universidad Rey Juan Carlos, Madrid). 
Abstract: Despite not having a formal treatise that encompasses economic thought, the Jewish tradition, through its legal and religious texts, tackles a wide range of economic subject matter. As early as Biblical times, Jewish law and Jewish moral doctrine began to govern economic activity and social life in general. Both of these continued to evolve until the 12th century when Moses ben Maimonides, interpreting and documenting the Jewish oral tradition laws (with Aristotelian influence as well as that of Ibn Bayya, among other philosophers), developed an individualistic, subjectivist, and rationalist moral philosophy exploring topics such as the theory of subjective value, the paradox of value, human action, the limits of reason, social cooperation, and division of labor.

This article investigates, from an Austrian School perspective, the economic thought contained in the Jewish tradition and its possible impact on the emergence of the capitalist system and modern civilization. Additionally, it explores the influence that the Jewish tradition and Maimonides' philosophy had on the doctrines of Saint Thomas Aquinas; doctrines which were taken and enriched by the Scholastics of Salamanca and are, according to some thinkers, the foundation of the Austrian School of Economics.

Keywords: capitalism, scholasticism, Judaism, laissez-faire.

JEL Classification: A13, B11, N01, Z12.

INTRODUCCIÓN

En cuanto a la posible conexión entre la tradición judía y el desarrollo histórico del pensamiento económico, ningún economista perteneciente a la Escuela Austriaca de Economía ha realizado un análisis específico.

Murray N. Rothbard, en la introducción de su obra Historia del Pensamiento Económico, afirmó que esa era la única obra que elaboraba una historia general del pensamiento económico desde una posición «austriaca». Menciona el citado autor, que las manifestaciones sobre cuestiones económicas en el Antiguo Testamento son dispersas, ambivalentes y hasta contradictorias. Destaca únicamente la repetida alabanza al trabajo que hace el texto bíblico y la aprobación de la usura en los préstamos realizados a los no judíos. 
En Historia del análisis económico, Joseph A. Schumpeter tampoco destaca la tradición judía en el desarrollo del pensamiento económico. Menciona, sin embargo, Schumpeter: «Los procesos que acabaron por hacer estallar el mundo social de Santo Tomás de Aquino se suelen mencionar conjuntamente con la expresión "nacimiento del capitalismo'"

Ludwig von Mises, máximo exponente de la Escuela Austriaca de Economía, fue judío de nacimiento, al igual que su discípulo Murray N. Rothbard. Su seminario en Viena, conocido como "Círculo de von Mises», estaba conformado por veintiséis economistas de los cuales veintitrés eran judíos².

Mises parece no haber considerado en sus escritos ningún aporte de la tradición judía al desarrollo del pensamiento económico. En su libro Omnipotent Government (1944), Mises niega que el liberalismo, la democracia, el capitalismo y el comercio internacional hayan sido invenciones judías ${ }^{3}$.

Gerhard Schmidt, nos ofrece una posición muy distinta a la de Mises en su obra La ética económica del judaísmo. En ella, defiende que la ética judía tuvo gran atracción para los griegos y llegó a ser una de las bases de la civilización occidental.

Importantes autores medievales defendían la misma tesis. Entre ellos, el filósofo musulmán Averrores, quien escribió: «No hay dudas que todas las ciencias se originaron entre los hijos de Israel, y la razón es la existencia de la profecía entre ellos, lo que hizo admirable su perfección en las ciencias». Clemente de Alejandría presentó toda la filosofía griega como un plagio directo de los hebreos e indirecto de fuentes caldeas y egipcias: «Se mostrará sin posible contradicción, que la sabiduría de los hebreos es la sabiduría más antigua». Influenciado por Clemente, Agustín afirmó que

\footnotetext{
${ }^{1}$ Véase Joseph A. Schumpeter, Historia del análisis económico, Editorial Ariel, Barcelona, 2004, p.111. Estas nociones de Santo Tomás resultan de interés, pues como se verá en la sección que trata el pensamiento de Maimónides, el judío cordobés, a quien el Aquinate denominaba con admiración «Moisés el egipcio», ya había tratado extensamente muchas ideas ulteriormente desarrolladas por Santo Tomás de Aquino.

${ }^{2}$ Gustavo Perednik, Notables pensadores judíos en la Civilización Occidental, ORT, Uruguay, 2006, p. 111.

${ }^{3}$ Véase Ludwig von Mises, Omnipotent Government, Yale University Press, Connecticut, 1944, p. 180.
} 
toda la sabiduría provenía de la: «doctrina profética, que manaba de la fuente de Israel». Haleví defendió la misma doctrina, con este pasaje: «Las raíces y principios de todas las ciencias pasaron de los hebreos primero a los caldeos, después a los persas y medos, luego a los griegos y finalmente a los romanos. Dado el largo tiempo y las muchas circunstancias perturbadoras, se olvidó que se habían originado con los hebreos, y así les fueron atribuidas a los griegos y romanos ${ }^{4}$ ».

Karl Marx escribiría en 1843 La cuestión judía, un ensayo que podría ser catalogado como judeofóbico, donde critica la base subjetiva e individualista del judaísmo, le reprocha sus «intereses egoístas» y califica al capitalismo de «judío».

Werner Sombart, distinguido economista y sociólogo alemán, realiza un análisis exhaustivo sobre la influencia judía en el capitalismo moderno. Lejos de la odiosa retórica de Karl Marx o la de Bruno Bauer, Sombart se adentra en el estudio histórico del capitalismo con mayor evidencia histórica.

En su obra The jews and modern capitalism ${ }^{5}$, estudia la contribución de los judíos a la vida económica moderna. En la misma, explica la importancia mayúscula que tuvo la presencia de comerciantes judíos en la prosperidad de los países europeos, y el rol prominente que jugaron los judíos en la expansión colonial, que fue una fuerza explicativa del desarrollo del capitalismo moderno. Asimismo, analiza en su libro la importancia de la religión judía en la vida económica, el «genio creativo» del judío, entre otros temas.

Sombart señala en su investigación, que eran los judíos quienes, en lo esencial, favorecían la expansión económica de los países dónde se instalaban; en sus palabras: «Israel passes over Europe like the sun: at its coming new life bursts forth; at its going all falls into decay ${ }^{6} »$. Expone Sombart, cómo a raíz de la expulsión de los judíos de España (1492), se da el florecimiento económico de las

\footnotetext{
${ }^{4}$ Véase Benzión Netanyahu, Don Isaac Abravanel, Estadista y Filósofo, Editorial Europa, Salamanca, 2004, pp. 129-130.

${ }^{5}$ Werner Sombart, The jews and modern capitalism, Batoche Books Limited, Ontario, 2011.

${ }^{6}$ La traducción al español de esta cita podría ser la siguiente: «Al igual que el sol, Israel pasa por Europa; donde llega, surge nueva vida; donde se aleja, decae lo que había sido floreciente». Werner Sombart, ob. cit., 2011, p. 13.
} 
ciudades donde estos se instalaron; en particular, la zona de los Pirineos. Sombart llega a afirmar que sin la dispersión de los judíos en los países del hemisferio norte del globo terrestre, no existiría el capitalismo ni la civilización moderna.

Su obra resalta el carácter individualista de la concepción judía de la economía, el entendimiento que se observa en sus tradiciones en cuanto a la división del trabajo, la comprensión del mercado como proceso competitivo; en resumen, expone: «I think that the Jewish religion has the same leading ideas as Capitalism. I see the same spirit in the one as in the other ${ }^{7}$ ». Afirma además, que el liberalismo es un pariente cercano del judaísmo, por lo que se podría componer la «terna de parientes: capitalismo, liberalismo y judaísmo».

Según Sombart, la tendencia teleológica, a veces llamada subjetividad extrema, está siempre presente en cualquier expresión del genio judío, y agrega: «the Jews are the most subjective of peoples... The entire universe, in the Jew's eyes, is something that was made in accordance with a plan. This is one of the differences between Judaism and heathenism ${ }^{8}$ ».

Las descripciones de Sombart de la tradición judía, con su enfoque individualista y subjetivista, la acercan a la praxeología de la Escuela Austriaca.

Werner Sombart asocia la escolástica católica de los siglos XIV y $\mathrm{XV}$ a las doctrinas filosóficas y morales del pueblo judío:

Opino que el proceso de formación de la doctrina moral escolástica durante los siglos XIV y XV se vio influido de modo decisivo por la evolución de la vida económica. Pero en esencia hemos de suponer que también el catolicismo de la Alta Edad Media bebió de fuentes que ni habían nacido entonces en aquellos lugares: vemos claramente cómo confluyen en él vivencias religiosas, la experiencia

${ }^{7}$ La traducción al español de esta cita podría ser la siguiente: «Pienso que la religión judía tiene las mismas ideas principales que el capitalismo. Veo el mismo espíritu tanto en la una como en la otra». Werner Sombart, ob. cit., 2011, p. 143.

${ }^{8}$ La traducción al español de esta cita podría ser la siguiente: «lo cierto es que los judíos son el más subjetivo de los pueblos... El universo entero, a los ojos del judío, es algo que se hace de acuerdo con un plan. Esta es una de las diferencias entre el judaísmo y el paganismo». Werner Sombart, ob. cit., 2011, p. 186. 
cotidiana, doctrinas filosóficas de tiempos antiguos y preceptos morales del pueblo judío?.

Marjorie Grice-Hutchinson, economista discípula de Friedrich von Hayek, investigó durante toda su carrera profesional la Escuela de Salamanca. Enfatizó en sus estudios la figura de Maimónides, y de modo muy somero abordó algunas de sus doctrinas económicas: «1) la ciencia económica y la ley judía; 2) el pensamiento económico y la justicia social; 3) la propiedad privada; 4) el precio justo; 5) el dinero y la banca; 6) la esclavitud; 7) el trabajo libre ${ }^{10}{ }_{\text {». }}$

Milton Friedman, influyente economista de origen judío perteneciente a la Escuela de Chicago, se refirió a lo que denominó la «paradoja judía» en su artículo académico Capitalism and Jews ${ }^{11}$.

Friedman alega, sustentándose en la argumentación de Sombart, que la tradición judía es históricamente pro-mercado y que ha sido campeona en la causa de la libertad individual frente a las visiones dominantes de las distintas épocas. No ha sido sino, desde mediados del siglo XIX, cuando muchos intelectuales judíos se han decantado por la ideología socialista. El motivo de esta afiliación al colectivismo, fue según Friedman, que el socialismo incorporaba una noción secular que permitiría integrar o asimilar al judío a la sociedad europea como un ciudadano más. En otras palabras, era un desesperado intento inconsciente por desasociar los estereotipos de mercader y usurero, de los que se tachaba a los judíos.

Es evidente que muy influyentes pensadores que han estudiado la historia del pensamiento económico, han dado un tratamiento contrapuesto a la herencia filosófica y moral judía.

Mediante un riguroso estudio cualitativo de fuentes primarias y secundarias, esta investigación busca establecer el vínculo entre las doctrinas de la tradición judía y la emergencia del sistema capitalista. Asimismo, depositar algo de contenido a ese aparente vacío

\footnotetext{
9 Werner Sombart, El burgués, Alianza Editorial, Madrid, 1972, p. 283.

${ }_{10}$ Marjorie Grice-Hutchinson, Aproximación al pensamiento económico en Andalucía: de Séneca a finales del siglo XVIII, Librería Ágora S.A., Málaga, 1990, p.47.

${ }^{11}$ Véase Milton Friedman, Capitalism and Jews, Foundation for Economic Education, 1 de octubre de 1988, https://fee.org/articles/capitalism-and-the-jews/. Accesado 16 de mayo de 2016.
} 
que existe entre el pensamiento económico de la tradición judía y las doctrinas de la Escuela de Salamanca.

\section{II \\ LA ÉTICA ECONÓMICA EN LA TRADICIÓN JUDÍA}

Para comprender el tratamiento que le da la tradición judía a distintos temas de naturaleza económica, social, legal y política; se utilizarán los principales textos y tratados que contienen normas y enseñanzas al respecto. A continuación se analizarán, desde una perspectiva austriaca, instituciones y tradiciones históricas del judaísmo.

\section{La vida, libertad y propiedad privada}

Los preceptos de la Ley de Moisés forman la base donde se asientan los fundamentos éticos de la tradición judía. La vida y la propiedad privada, son considerados según la tradición judía «derechos naturales», tan inmutables que fueron escritos en piedra ${ }^{12}$.

La vida tiene un valor supremo y absoluto según el judaísmo, por lo que la autodefensa no es solo un derecho, sino que es una obligación ${ }^{13}$; asimismo, se obliga al judío a defender la sangre del prójimo $^{14}$.

El Talmud enseña: «Quien destruye una vida, es como si destruyera todo un mundo y quien salva una vida, es como si hubiera salvado un mundo entero ${ }^{15}$ ». La concepción judía de la vida es individualista y subjetivista. Para cada individuo su vida es el mundo

${ }^{12}$ De los diez mandamientos que Moisés recibe en el Sinaí, tres son positivos: amar a Dios, santificar las fiestas, y honrar al padre y a la madre; y siete son negativos: no usar el nombre de Dios en vano, no matar, no cometer actos impuros, no robar, no dar falso testimonio, no consentir pensamientos impuros y no codiciar los bienes ajenos.

13 Talmud, Sanhedrín, 72a.

${ }^{14}$ Talmud, Sanhedrín, 73a.

15 Talmud, Sanhedrín, 4:9. 
entero. A diferencia de otras culturas, como la griega, en la cual el individuo era sólo parte de la polis; según el judaísmo cada vida es un fin en sí mismo, lo que implica que cada individuo es poseedor de su vida, sus elecciones y el fruto de las mismas.

La concepción individualista del hombre y la sociedad, que hace la tradición judía, es compatible con el individualismo metodológico, base de la praxeología de la Escuela Austriaca ${ }^{16}$.

La libertad tiene una importancia trascendental en la tradición judía. En el primer mandamiento, Dios no se muestra como creador del mundo, sino que se declara libertador del pueblo judío: «Yo soy el Eterno, tu Dios, que te sacó de la tierra de Egipto, de la casa de la servidumbre ${ }^{17}$ ». La libertad, entonces, según la tradición bíblica es el evento central de la narrativa de la Torá y el gesto que Dios hizo por el pueblo judío que mayor gratitud merece.

Cabe señalar con referencia a la libertad, que la tradición judía desde tiempos bíblicos, atribuye a todo hombre el libre albedrío. Según la tradición judía, todo hombre es responsable de sus decisiones, y estas juegan un rol activo en su destino ${ }^{18}$. Justamente, el libre albedrío es la concepción praxeológica de la libertad. En palabras de Ludwig von Mises: «Consideramos libre, desde el punto de vista praxeológico, al hombre cuando es libre de actuar de un modo o de otro, es decir, cuando puede personalmente determinar sus objetivos y elegir los medios que estime mejores ${ }^{19}{ }^{\prime}$.

La institución de la propiedad privada es aceptada como axiomática, y su defensa es categórica en la tradición judía.

El derecho de propiedad sobre tierras desiertas o sin dueño, se obtiene al ocuparlo e incorporarle trabajo. El Talmud enseña en que

${ }^{16}$ Todas las leyes y teorías económicas que constituyen el edifico teórico de la Escuela Austriaca, son retrotraibles a la acción humana, que es: «una conducta consciente, movilizada voluntad transformada en actuación, que pretende alcanzar precisos fines y objetivos; es una reacción consciente del ego ante los estímulos y las circunstancias del ambiente; es una reflexiva acomodación a aquella disposición del ambiente que está influyendo en la vida del sujeto». Véase, Ludwig von Mises, La acción humana, Unión editorial, Madrid, 2015, p. 15.

17 Antiguo Testamento, Éxodo, 20:2.

${ }^{18}$ En la parte de la filosofía de Moisés ben Maimónides se tratará en detalle el libre albedrío.

${ }^{19}$ Ludwig von Mises, La acción humana, Unión Editorial, 2015, p. 340. 
para que la propiedad sea adquirida, el trabajo incorporado a la misma debe derivar en una mejora de su condición misma.

La concepción judía de la adquisición de la propiedad presente en el Talmud parece fundamentar la doctrina de John Locke, a la cual se adscriben una parte importante de los economistas de la Escuela Austriaca de Economía ${ }^{20}$.

El Mishné Torá, expone que «la posesión de la tierra jamás puede adquirirse de manos de un asaltante, sino que siempre permanece en posesión de sus legítimos dueños; aunque se la haya vendido a mil, uno tras otro, y los dueños hayan perdido la esperanza, retorna sin pago a manos del despojado ${ }^{21} \gg$. El principio anterior encaja también con la ética libertaria ${ }^{22}$.

Igual que con la tierra, es expresamente prohibido comprarle al ladrón el objeto robado ${ }^{23}$. Se debe devolver siempre lo encontrado. En caso de que el bien no tenga marcas de identificación, y se considera que el dueño ha perdido la esperanza de recobrarlo, es propiedad de quien lo haya encontrado.

La herencia es inviolable, y ni siquiera el rey puede disponer de los bienes de sus súbditos. Se menciona en la Biblia: «el príncipe no tomará nada de la herencia del pueblo, desposeyéndolo indebidamente. Dará herencia a sus hijos de sus propias posesiones, para que ninguno de Mi pueblo sea privado de su posesión ${ }^{24} \gg$.

${ }^{20}$ En cuanto a la apropiación de los frutos de la naturaleza, dice Locke que al recogerlos pasan a manos de quien hizo el acto, pues: «El trabajo puso un sello que lo diferenció del común. El trabajo agregó a esos productos algo más que lo que había puesto la Naturaleza, madre común de todos, y, de ese modo, pasaron a pertenecerle particularmente». En cuanto a la apropiación de la tierra, Locke defiende una postura prácticamente idéntica a la del Talmud: «Por idénticas medidas se regía la apropiación de la tierra. El hombre tenía un derecho especial a las tierras que cultivaba y cosechaba, así como a los productos que recogía y aprovechaba antes que se echasen a perder; también le pertenecían, pues, todo el ganado y las cosechas de la tierra por él cercada y que era capaz de cuidar y aprovechar. Pero si dejaba que la hierba de la tierra de su propiedad se pudriese allí mismo o que los frutos de su cultivo se echasen a perder sin recogerlos, esa parcela de tierra, a pesar de estar cercada, debía considerarse desierta y podía otro apropiarse de ella». Véase John Locke, Ensayo sobre el Gobierno Civil, Aguilar S.A. de Ediciones, Madrid, 1990, pp. 37-49.

21 Moisés ben Maimónides, ob. cit., 1998, p. 220.

22 Murray N. Rothbard, ob. cit., 2015.

23 Proverbios, 29:24.

${ }^{24}$ Profetas, Ezequiel, 46:18. 
La Escuela Austriaca defiende la propiedad privada, por ser la piedra angular del sistema capitalista. Este orden espontáneo, permitió la supervivencia y progreso de las sociedades que la adoptaron, y generó también la transición de la sociedad tribal a la sociedad civilizada $u$ orden extenso ${ }^{25}$.

\section{Trabajo y responsabilidad individual}

El trabajo, como medio para el sustento independiente, es según la tradición judía una gran virtud. En todos los escritos religiosos se hace referencia a la importancia del trabajo y la responsabilidad individual. El trabajo, además de permitir el sustento material, tiene un componente emocional y espiritual, pues honra a quien lo realiza y aleja del pecado ${ }^{26}$.

La tradición judía es muy clara en cuanto a la responsabilidad individual de procurar el sustento del hogar. Los tratados enseñan sobre cómo planificar la vida, de modo tal que la persona sea económicamente independiente, antes de emprenden la vida familiar. $\mathrm{Al}$ respecto instruyen:

Es manera prudente de obrar, que ante todo un hombre elija un oficio para mantenerse, después compre una casa para vivienda y finalmente tome esposa. Pero los necios empiezan por tomar esposa; después, si pueden, comprarán una casa, y más tarde aún, ya al fin de sus días, andarán buscando oficio o vivirán de la caridad ${ }^{27}$.

\footnotetext{
${ }^{25}$ Véase por ejemplo F.A. Hayek, La fatal arrogancia, Unión Editorial, Madrid, 2010.

${ }^{26}$ La Biblia predica: «Con el sudor de tu rostro comerás el pan, hasta que retornes a la tierra, ya que de ella fuiste tomado, pues polvo eres y al polvo volverás (Génesis, 3:19)». El Rey Salomón escribió: «Cuando comas el fruto de la labor de tus manos, feliz serás y te irá bien (Salmos, 128:2)». El Talmud enseña: «Grande es el trabajo pues honra a quien lo realiza (Nedarim, 49b)». Maimónides dice que quien no trabaja «termina despojando a la gente (Maimónides, 1998, pág. 26)». El Rabino Hillel enseñó la importancia de la responsabilidad individual, de la solidaridad y de la inmediatez de la acción, al preguntar: «¿Si no soy para mí, quién será para mí? ¿Si yo soy (solamente) para mí, qué soy yo? ¿Si no es ahora, cuándo? (Pirkei Avot, 1, 14)».

${ }^{27}$ Moisés ben Maimónides, ob. cit., 1998, p. 18.
} 
La tradición judía pregona que el aprendizaje de un oficio es la mejor forma para evitar caer en la indigencia y delincuencia. Esa tarea no es responsabilidad de la «sociedad», sino que del padre: «Dijo el rabí Iehudá: El que no enseña a su hijo un oficio a su hijo, le enseña a saquear ${ }^{28} \gg$.

\section{Ahorro, capital y riqueza}

El ahorro es una institución bíblica. Su importancia es transmitida en la alegoría de las vacas flacas y las vacas gordas. En este episodio del Génesis ${ }^{29}$, José se convierte en consejero del faraón por haber logrado prever una hambruna. La moraleja es la importancia del ahorro y su utilidad para afrontar la incertidumbre a la que la humanidad se ve expuesta.

La tradición judía otorga una importancia particular a la conservación de la propiedad de la tierra, y en general, da un trato virtuoso a la acumulación de bienes perennes.

Maimónides advierte que la vida humana sólo es posible gracias a la división del trabajo y ejecución de largos procesos productivos, provistos de muchos instrumentos; o sea, bienes de capital:

Porque los alimentos de que el hombre se mantiene exigen arte y largos preparativos, que no se consiguen sino a fuerza de pensar y reflexionar, con ayuda de muchos instrumentos y con el concurso de muchas personas, cada una de las cuales se encarga de una tarea en particular ${ }^{30}$.

Enseña la Escuela Austriaca que la acumulación de capital bien invertido, es el modo de aumentar la productividad de la sociedad y enriquecerla. Para poder formar capital es necesaria una renuncia temporal al consumo; o sea, el ahorro es requisito fundamental para aumentar el stock de capital en la sociedad.

${ }^{28}$ Talmud, Kidushim, 29a.

29 Antiguo Testamento, Génesis, 41.

${ }^{30}$ Moisés ben Maimónides, Guía de los descarriados, Editorial S. Sigal, Buenos Aires, 1977, p. 232, vol. I. 
A diferencia de las concepciones de la riqueza de otras culturas, según la tradición judía, la riqueza es una situación deseable, pues ayuda a servir a Dios. Al respecto enseña el Talmud: «los beneficios adquiridos como fruto del trabajo tienen tanto valor como el temor a Dios ${ }^{31} »$; asimismo, menciona: «El dinero facilita la vida del hombre $^{32} \gg$.

En varias escrituras de los primeros siglos después de Cristo, se observa una concepción subjetiva la riqueza ${ }^{33}$. Al respecto, encontramos lo dicho por Rabbi Natán: «En tiempos de escasez, el hombre aprende a valorar más la riqueza ${ }^{34} »$; así como la enseñanza del Pirkei Avot: «¿Quién es rico? Aquel que se regocija con su parte ${ }^{35}$ ».

A diferencia de algunos paganos, ascetas y anacoretas de la época, y ulteriores corrientes de pensamiento como el calvinismo; la tradición judía no permite al judío excederse en cuanto a lo que las restricciones establecen; o sea, es prohibido privarse de goces o autoimponerse sufrimientos innecesarios ${ }^{36}$.

\section{La caridad como institución voluntaria}

La caridad es considerada por la tradición judía, como el precepto más importante. Se dice que quien ayuda al prójimo se beneficia también a sí mismo, pues «adquiere para sí un alma de bondad».

La caridad es responsabilidad de cada individuo para con el prójimo menesteroso, no una responsabilidad del «Estado» o de un ente abstracto como la «Sociedad».

\footnotetext{
31 Talmud, Berajot, 8a.

32 Talmud, Sanhedrín, 11:3.

${ }^{33}$ Cómo se desarrollará más adelante, Maimónides, en el siglo XII, con fundamento en los escritos de Ibn Paquda llega a asociar la escasez con el valor, pasando de una comprensión de la subjetividad de los medios, a un esbozo sobre la teoría de la utilidad marginal. «En efecto, en medida que una cosa es más necesaria al animal, se la encuentra más frecuentemente y es de precio más vil; y a medida que una cosa es menos necesaria, se la encuentra menos y es muy cara». Véase Moisés ben Maimónides, ob. cit., 1977, p. 51, Vol. III.

${ }^{34}$ Avot de Rabbi Natán, 4e.

${ }^{35}$ Pirkei Avot, 4:1.

${ }^{36}$ Moisés ben Maimónides, ob. cit., 1998, p. 15.
} 
La tradición judaica protege de modo especial al pobre, al extranjero, a la viuda y al huérfano. La Biblia es explícita al ordenar el cumplimiento del precepto de tzedaká o caridad, y enseña: «obra de la caridad será la paz ${ }^{37} \gg$.

Comenta Maimónides, que el precepto de la caridad debe cumplirse con mucho mayor celo que cualquiera de los otros numerosos preceptos; pues la caridad es «la señal distintiva del hombre justo, de la simiente de Abraham ${ }^{38}$ ».

De los ocho grados de caridad, el más alto y supremo de todos, es el del que acude en ayuda del judío necesitado, dándole un obsequio o un préstamo, tomándolo como socio, o proveyéndole una tarea que pueda hacer hasta que se recupere y no necesite acudir más a la caridad. La caridad preventiva es preferible a la paliativa, en el tanto permite al auxiliado llegar a ser autosuficiente.

En algunas comunidades judías existía una olla popular o $\mathrm{Ta}$ mjuy, que consistía en donaciones en alimentos o dinero, que eran recogidas en los patios de los ciudadanos y entregados en las noches a los pobres para que se sustentaran ${ }^{39}$.

A pesar que debe evitarse al máximo ser objeto de caridad, el viejo, enfermo o achacado, que necesite tomar de la caridad y no pueda vivir sin ello, pero no lo hace por orgullo, es culpable de derramamiento de sangre y comete pecado mortal.

Maimónides menciona que la institución la beneficencia es ubicua en el mundo judío; en sus palabras: «jamás hemos visto ni oído de una comunidad judía que no tuviera su kupá de beneficencia ${ }^{40}$ ».

Esta realidad histórica contrasta con los temores de muchos ciudadanos de los «Estados del bienestar», que creen que sin asistencia social del Estado, no habría solidaridad humana para los que caen en desgracia. Es comprensible que esta errada intuición contemporánea se fundamente en la costumbre de observar cómo la intromisión estatal en los procesos naturales de cooperación humana, hace desvanecer la naturaleza solidaria de los individuos.

\footnotetext{
37 Profetas, Isaías, 32:17.

38 Moisés ben Maimónides, ob. cit., 1998, p. 157.

39 Moisés ben Maimónides, ob. cit., 1998, p. 156.

40 Moisés ben Maimónides, ob. cit., 1998, p. 156.
} 


\section{El comercio}

La vida económica judía durante los últimos dos milenios, giró mayormente en torno al comercio y la usura. Los judíos, dada su condición apátridas, tuvieron que dedicarse a este tipo de servicios, pues en muchos lares carecían de tierras y de modo reiterado eran obligados a migrar.

La legislación talmúdica y post-talmúdica, ha defendido la libertad comercial y el precio fijado voluntariamente entre las partes. Los únicos artículos cuyos precios estaban regulados eran aquellos de primera necesidad ${ }^{41}$. Ahora bien, si las partes estaban enteradas mediante la «palabra de honor» que la ganancia excedía eso, el comprador no podía acusar por fraude. Asimismo, esta ley no aplicaba a los bienes inmuebles, esclavos y escrituras, aunque «uno los venda por un denario valiendo mil o por mil valiendo uno ${ }^{42}$ ».

La tradición judía prohíbe absolutamente los engaños ${ }^{43}$. Respecto a la exactitud de pesos, balanzas y medidas, la ley judía es muy estricta ${ }^{44}$. En las comunidades judías existían inspectores que visitaban mercados, para verificar los pesos y medidas que utilizaban los comerciantes ${ }^{45}$.

El Talmud, el Mishné Torá y el Shulján Aruj, avalan la libre competencia, y aunque los comerciantes se quejen, no es permitido obstaculizar la labor de los vendedores ambulantes que viajan de ciudad en ciudad ${ }^{46}$. Asimismo, esos tratados mencionan que es permitido dar nueces a niños como táctica para atraer clientes ${ }^{47}$. Es

\footnotetext{
${ }^{41}$ Se permitía a lo sumo un margen de ganancia de $1 / 6$ sobre la venta; lo que es lo mismo que un $20 \%$ sobre el costo. Véase Moisés ben Maimónides, ob. cit., 1998, p. 250.

${ }^{42}$ Moisés ben Maimónides, ob. cit., 1998, p. 249.

${ }^{43}$ Moisés ben Maimónides, ob. cit., 1998, p. 251.

44 “No falsificarán las mediciones en tamaño, en peso ni en volumen. Tendrán balanzas justas, pesas justas, medidas secas justas y medidas líquidas justas. Yo soy el Eterno su Dios, que los saqué de la tierra de Egipto". Antiguo Testamento, Levítico, 19:35-36.

45 «Los dirigentes de la comunidad tienen la obligación moral de designar inspectores que se dediquen a inspeccionar los negocios, e imponer castigos y multas según convenga el caso, a aquellos que tienen medidas y pesas deficientes o balanzas defectuosas». Iosef Caro, Kitzur Shulján Aruj, Editorial Yehudá, Buenos Aires, 1979, p. 37, Vol. II.

46 Talmud, Babá Batrá, 21b.

47 Talmud, Babá Batrá, 21b.
} 
permitido vender a precios más bajos que los del mercado y los demás comerciantes no podrán oponerse a ello ${ }^{48}$.

En cuanto al tratamiento del comercio en otras culturas, el derecho romano defendió el derecho de propiedad privada y el laissezfaire. El precio justo era «cualquier precio acordado tras libre y voluntario regateo entre comprador y vendedor ${ }^{49}{ }$.

La actitud de los primeros cristianos, incluyendo a Jesús, fue de ocuparse por el advenimiento del Reino de Dios y olvidarse de asuntos mundanos. Por lo que la condena a la acumulación de riqueza de los mismos fue clara. Ulteriormente, los padres de la Iglesia también arremetieron contra las actividades mercantiles ${ }^{50}$.

Clemente de Alejandría ${ }^{51}$, quien nació a mediados del siglo II d.C., fue el padre de la Iglesia quien más inteligentemente defendió la acumulación de riqueza y propiedad privada ${ }^{52}$. Dos siglos más tarde, San Agustín fue el primer padre de la Iglesia en adoptar una actitud positiva hacia la función del comerciante.

\section{La ética de trabajo}

La legislación judía establece normas tanto para el patrono como para el empleado; además, detalla las condiciones de la esclavitud; tanto voluntaria como obligatoria.

Se consideran las relaciones laborales como contratos de mutuo beneficio; por lo que ambas partes deben cumplir sus compromisos. Así como el empleador es advertido contra cualquier intención de robar el salario del trabajador y se le exige pagar en su debido tiempo ${ }^{53}$, también el trabajador es prevenido contra cualquier propósito de robar al patrón holgazaneando ${ }^{54}$.

48 Shulján Aruj, 228:18.

${ }^{49}$ Murray N. Rothbard, Historia del pensamiento económico, Madrid, 2015, p. 59.

${ }^{50}$ Murray N. Rothbard, ob. cit., 2015, pp. 59-62.

${ }^{51}$ Como ya se mencionó, Clemente presentó toda la filosofía griega como un plagio de la sabiduría hebrea, la que consideró «la sabiduría más antigua».

${ }^{52}$ Murray N. Rothbard, ob. cit., 2015, p. 62.

53 «Es un mandamiento positivo pagarle al asalariado a su debido tiempo, como está escrito: "Le pagarás su sueldo en el mismo día (Deuteronomio XXIV, 15)"». Moisés ben Maimónides, ob. cit., 1998, p. 275.

${ }^{54}$ Moisés ben Maimónides, ob. cit., 1998, p. 279. 
El empleado puede renunciar cuando así lo desee ${ }^{55}$, no así ser despedido en cualquier momento; pues se entiende que al carecer de otro sustento que el que le proporciona su trabajo, se encuentra en posición vulnerable. La jornada laboral es a lo sumo de seis días, pues el día Shabat es de descanso obligatorio; y en caso de excederse el horario pactado, el patrono debe reconocer pagos extraordinarios por unidad de tiempo.

La Biblia permitía el comercio de esclavos de otras naciones, los cuales servían a perpetuidad ${ }^{56}$. El esclavo hebreo era aquel condenado por un tribunal a la servidumbre, o aquel que se vendía voluntariamente para acumular dinero ${ }^{57}$. El israelita que se vendía voluntariamente tenía que ser sumamente pobre, y sólo podía vender su libertad si era esta la única manera de alimentarse. Una mujer no podía ser vendida por el tribunal por haber robado, ni ella misma venderse.

Al esclavo hebreo no se le podía tratar de forma cruel, debía definírsele su tiempo de trabajo y funciones. Debía ser tratado en iguales condiciones que el mismo amo se daba a sí mismo: comer el mismo tipo de pan, beber el mismo tipo vino, dormir en mismo tipo de cama y almohada, además debía vivir en misma aldea ${ }^{58}$. Una vez el esclavo era liberado, no se le dejaba ir con las manos vacías, sino que se le proveía generosamente con animales, cereales y vino ${ }^{59}$. De hecho, enseña el Talmud: «el que ha comprado un esclavo hebreo es como el que ha adquirido un amo para $\mathrm{si}^{60} \%$.

El esclavo vendido por un tribunal, quedaba en libertad después de seis años de servicio ${ }^{61}$. Aquel que se vendía para la servidumbre voluntariamente, podía hacerlo por un lapso mayor de seis años. El esclavo hebreo, ya fuera vendido por tribunal o voluntario, siempre podía pagar su rescate para liberarse, pagando el tiempo no laborado ${ }^{62}$.

\footnotetext{
55 Talmud, Baba Kama, 116b.

56 Antiguo Testamento, Levítico, 25: 44-46.

57 Moisés ben Maimónides, ob. cit., 1998, p. 268.

58 Talmud, Kidushim, 20a.

59 Antiguo Testamento, Deuteronomio, 15:13-14.

60 Talmud, Kidushim, 20a.

61 Antiguo Testamento, Éxodo, 21:2.

62 Moisés ben Maimónides, ob. cit., 1998, p. 269.
} 
Los esclavos cananeos (no hebreos), eran principalmente prisioneros de guerra. Aunque legalmente no era prohibido ser implacable con ellos, las normas de convivencia imponían un trato misericordioso y justo para con todo ser humano ${ }^{63}$. Su servidumbre terminaba por varios motivos; entre ellos: el pago de dinero por un tercero, su conversión al judaísmo y su liberación ulterior, si era víctima de lesiones corporales graves causadas por su amo, si contraía matrimonio con una mujer libre, entre otras.

\section{La usura}

El judaísmo es la primera religión que en los albores del segundo milenio a.C. condena frontalmente la usura. El Pentateuco recoge la prohibición explícita a la usura, mientras que las culturas contemporáneas, como la babilonia, egipcia e india, sólo regulaban la tasa de interés ${ }^{64}$.

El judaísmo veía el préstamo sin intereses como una de las maneras más nobles de ejercer el precepto de la caridad. Dice la Biblia: «Si tu hermano padeciere estrechez (económica), lo acogerás como a forastero y a peregrino, para que viva contigo. No le prestarás dinero a interés y no le darás tu comida con intención de ganancia $^{65}{ }^{6}$. En Deuteronomio; sin embargo, se establece la permisión del préstamo con interés al extranjero ${ }^{66}$.

En el medioevo, los judíos no podían poseer tierras, por lo que se dedicaban a trabajos de servicios, como: prestamistas, agentes comerciales y médicos. Se crean en la época subterfugios legales para que los judíos pudieran prestarse entre ellos, sin que el préstamo significara siempre un sacrificio para el prestamista.

Entre los recursos que se crean está la figura del Prozbol ${ }^{67}$, instaurada por Hillel en tiempos de Cristo, que consistía en un contrato con la renuncia explícita a la extinción del préstamo en el

\footnotetext{
${ }^{63}$ Moisés ben Maimónides, ob. cit., 1998, p. 270.

${ }^{64}$ Mario Matus, Trayectoria de la usura y lucro en el judaísmo, Cuadernos judaicos, 2013, pp. 100-121.

${ }_{65}$ Antiguo Testamento, Levítico, 25:35-37.

${ }_{66}^{6}$ Antiguo Testamento, Deuteronomio, 23:21.

${ }^{67}$ Moisés ben Maimónides, ob. cit., 1998, p. 169.
} 
séptimo año o en los años jubileos, que eran períodos de 50 años donde todas las deudas eran condonadas y los esclavos liberados.

Ya para el primer milenio de la era actual, Rashi ${ }^{68}$ autoriza el uso de terceros o "amigos», para contraer u otorgar préstamos. Asimismo, se formaliza la institución de hacer ver un préstamo como un negocio que realiza el prestatario para el prestamista.

De modo opuesto a la flexibilización de usura por parte de las autoridades judías, el cristianismo emprende la condena contra la usura.

En el siglo XVI, el Shulján Aruj, fundamentado en las leyes del Talmud y en el Mishné Torá de Maimónides, establece que aun cuando el préstamo con intereses es voluntario y en apariencia es de gran beneficio para las partes, sigue siendo condenable ${ }^{69}$.

Sin embargo, entendiendo la necesidad práctica de un sistema de préstamos, surge un nuevo subterfugio. Textualmente se establece: «El estigma de cobrar interés puede ser evitado de la siguiente manera: Rubén, que requiere un préstamo para el mes de Nisán, pide a Simón que le entregue un pagaré en el cuál Simón se obliga a sí mismo a pagar a Rubén, cien monedas de oro en el mes de Tishrí; y para cubrir a Simón de cualquier pérdida, Rubén le extiende a él un pagaré para el mismo monto y también con vencimiento en el mes de Tishrí. Rubén puede ahora vender el pagaré que le entregó Simón a Leví por noventa monedas de oro ${ }^{70}$ ».

También el Shulján Aruj describe un mecanismo para préstamos a corto plazo que consiste en que el "prestatario» aprovecha una oportunidad de negocio con dinero prestado. Para simular una asunción de riesgo, el prestamista debe llevar la mercancía hasta la

\footnotetext{
${ }^{68}$ Rashi es considerado el más excelso comentarista de la Biblia y el Talmud.

69 «Forma parte de la naturaleza humana aspirar a la adquisición de riquezas. Pero de todas las operaciones comerciales ilegales la usura es la más común. En el robo o en el fraude, la víctima trata habitualmente de defenderse y el delincuente se ve inhibido, a menudo, por la vergüenza o el temor. Cuando una persona percibe intereses por un préstamo, el prestatario los paga voluntariamente. Más aún: se siente feliz de haber podido encontrar una persona de quien pudo obtener un préstamo aunque fuera a un alto tipo de interés. Y el prestamista se halla bajo la impresión de estar haciendo un gran favor al prestatario, quien puede, mediante el préstamo, ganar con creces el monto de interés. De ahí que sea muy fácil Dios no quiera - caiga en la trampa de la usura." Iosef Caro, ob. cit., p. 42, Vol. II.

${ }^{70}$ Iosef Caro, ob. cit., p. 45.
} 
casa del prestatario y así puede proceder a cobrar más del monto prestado.

Como se observa, la usura parece ser admitida, en el tanto se materialice en un documento que es descontado por un tercero, $\mathrm{o}$ bien, exista asunción de riesgos.

\section{Depósitos y préstamos}

El tema de los depósitos y préstamos es desarrollado en diversos escritos y tratados. Entre ellos: los escritos de Filón de Alejandría ${ }^{71}$, el Talmud, el Mishné Torá y el Shulján Aruj.

En tiempos de Cristo, Filón de Alejandría demostró un discernimiento cabal en cuanto a la institución del depósito y la del préstamo. Consideró que un depósito es «el más sagrado de los tratos», pues se hace en secreto con la «buena fe» del que lo recibe como garantía. El que custodia «devolverá el depósito cuando le sea requerido»; y sentencia el Filón que debe tener presente «quien se niega a devolver un depósito, que está cometiendo un gravísimo delito ya que ha defraudado las esperanzas de quien se lo entregón ${ }^{72} \gg$.

${ }^{71}$ También conocido como «Filón el judío», nació en Alejandría aproximadamente en el año 13 a.C. en una familia de alta posición. Este exégeta judío es uno de los filósofos más renombrados del judaísmo helénico. Se le atribuye la armonización de la cultura judía y griega. Su pensamiento, que abordó: historia, legislación, filosofía, hermenéutica, entre otras; despertó el interés de exégetas cristianos, que desde los orígenes de la «fundamentación teológico-filosófica de la doctrina evangélica, hallaron en sus obras una fuente inagotable de teorías y conceptos adaptables a las creencias básicas del cristianismo». Se cree que el alejandrino falleció en sus ciudad natal, entre los años 45 y 50 d.C.

${ }^{72}$ En sus palabras: «30. VII. El más sagrado de los tratos que se conciertan entre los hombres es el depósito que una persona confía a otra, cuando la garantía es la buena fe del que lo recibe. Porque, tratándose de préstamos, las seguridades están dadas por los contratos y documentos escritos, y en el caso de los artículos entregados públicamente para su uso sin las formalidades de los préstamos están de testigos los que han presenciado la entrega. 31. En cambio, el procedimiento seguido en el caso de los depósitos no es ese. En ellos una persona entrega a otra por su propia mano en secreto, hallándose ambos solos, mientras inspecciona en torno de sí el lugar, al que ha acudido sin traer consigo esclavo alguno, ni siquiera uno leal, para transportar lo que lleva. Es que uno y otro están evidentemente empeñados en que la cosa pase inadvertida, uno para no ser visto al hacer la entrega, y el otro para que no se sepa que 
Prodigiosamente se pronuncia en contra del uso de la reserva fraccionaria de los depósitos confiados a los banqueros. El alejandrino desarrolla alegóricamente esa idea así:

102. Sabido es que los pescadores sueltan pequeños peces a modo de cebo para pescar los peces mayores y que esto es solo a medias reprochable, pues pueden argüir que están procurando el acopio de una abundante mercadería para el mercado y que asegurarán a la gente inagotable provisión para la mesa diaria. 103. Nadie, pues, haga una ostentosa devolución de alguna insignificante suma adeudada con miras a la caza de una suma mayor, tendiendo con las manos la pequeña suma de uno solo y apropiándose con las intenciones de las sumas incalculables de todos ${ }^{73}$.

La obra de Filón insiste reiteradamente en condenar esta vil práctica que era común en la época ${ }^{74}$. Del mismo modo, denuncia la práctica de usar el pago de intereses como señuelo para conseguir la confianza de los depositantes y aumentar la captación de fondos y ganancias ${ }^{75}$.

la ha recibido. Mas en este invisible trato es sin duda intermediario el invisible Dios, quien, naturalmente, es invocado como testigo, por uno de que devolverá el depósito cuando le sea requerido, por el otro de que lo recobrará en su debido momento. 32. Tenga, pues, presente quien se niega a devolver un depósito, que está cometiendo un gravísimo delito ya que ha defraudado las esperanzas de quien se lo entregó, ha disimulado con amables palabras lo vil de su carácter, ha disfrazado su deslealtad bajo la máscara de una lealtad bastarda, y ha hecho que las seguridades dadas al extender su diestra se conviertan en la negación de lo convenido y que los juramentos queden incumplidos. De donde resulta que ha despreciado tanto las cosas humanas como las Divinas, y ha desconocido dos depósitos: el de aquel que le confió sus bienes y el de Aquél que, siendo el más veraz de los testigos, observa y escucha cuanto hacen y dicen todos, y en qué medida están o no dispuestos a hacer lo que dicen». Filón, Obras completas de Filón de Alejandría, Acervo Editorial, 1975, p. 398, vol. IV.

${ }^{73}$ Filón, ob. cit., p. 178, vol. II.

74 «105. XXII. Innumerables son, en efecto, los que niegan los sagrados depósitos y por desmedido engreimiento usan lo que pertenece a otro como si le perteneciera. Pero tú, amigo, procura no sólo conservar intacto e inalterado lo que has tomado, sino también tenerlo por digno de todo cuidado, a fin de que el que te lo ha confiado en depósito no tenga nada que echarte en cara en tu custodia». Filón, ob. cit., p. 29, vol. III.

75 «67. Así, no faltan ejemplos de quien, habiendo recibido un depósito de poco valor, lo reintegró más para tender un lazo al que lo recobraba que para beneficiarlo, pues su intención era poner la probidad como señuelo en cosas de poca monta, para ganarse la confianza en las importantes, lo cual no es otra cosa que hacer justicia pero 
El Talmud, establece cuatro clases de depositarios: el depositario gratuito, el prestatario, el depositario pago y el arrendatario.

El depositario gratuito, debe declarar con juramento en todos los casos que el depósito sufre un deterioro o se pierde. Queda libre de responsabilidad cuando no ha mediado negligencia de su parte. El prestatario, debe pagar en todos los casos, incluso en caso de accidentes inevitables. El depositario pago y el arrendatario, deben jurar cuando se trata de un animal que sufrió heridas, fue capturado o murió, pero deben pagar en caso de pérdida o robo ${ }^{76}$.

El depositario tiene la prohibición de tocar lo que se le ha dejado en depósito. Sólo en caso de productos perecederos que estén echando a perder, dice Rabí Shimeón ben Gamaliel, que debe venderlos con autorización judicial, porque es como devolver objetos perdidos a su dueño ${ }^{77}$.

Cuando a un cambista le dejan en depósito dinero empaqueta$\mathrm{do}^{78}$, no debe usarlo; por eso si se pierde no es responsable. Si le dejan dinero suelto, puede usarlo y si se pierde, entonces sí es responsable. Cuando le dejan dinero a un particular, no debe usarlo, esté empaquetado o suelto; por eso, si se pierde no es responsable ${ }^{79}$.

En el siglo XI d.C., el Mishné Torá de Maimónides, sigue la misma línea de las enseñanzas del Talmud ${ }^{80}$.

Para finales del siglo XVI, el Shulján Aruj, adaptándose a las tendencias de la época, establece que la figura de depósito tiene tácitamente carácter de préstamo. Esto significa un retroceso al tratamiento del depósito irregular que habían ofrecido Filón y las discusiones rabínicas de los primeros siglos de la era común. En palabras del tratado: «Hoy en día, cuando todos nos dedicamos a

de manera injusta, por cuanto, si bien el reintegro de lo que pertenece a otro es justo, no lo es el modo como se ha procedido, dado que ha sido con miras a perseguir mayores ganancias». Filón, ob. cit., p. 407, vol. IV. Cabe destacar que las reflexiones de Filón podrían tener particular importancia histórica. Jesús Huerta de Soto en su Dinero, crédito bancario y ciclos económicos, estudia ampliamente el desarrollo histórico de la figura de depósito irregular a lo largo de los últimos dos milenios.

76 Talmud, Baba Metsía, 93a.

77 Talmud, Baba Metsía, 38a.

${ }^{78}$ Se acostumbraba es ese tiempo a atar y sellar el dinero con un nudo especial para que el cambista no lo abriera y usara.

${ }^{79}$ Talmud, Baba Metsía, 43a.

${ }^{80}$ Moisés ben Maimónides, ob. cit., 1998, p. 273. 
los negocios y constantemente necesitamos dinero, podemos dar por seguro que cuando alguien da dinero en depósito, tácitamente accede a que el depositario utilice el dinero si lo necesita. Por lo tanto, el dinero depositado asume el carácter de préstamo ${ }^{81}{ }^{1}$.

La Teoría del Ciclo Económico de la Escuela Austriaca de Economía, establece que el origen de los ciclos económicos se da en la expansión crediticia sin respaldo de ahorro efectivo, que realiza la banca mediante los contratos de depósito irregular con reserva fraccionaria ${ }^{82}$. Por lo anterior, los más importantes exponentes de la Escuela Austriaca de Economía condenan la violación que cometen los bancos al tomar depósitos irregulares cual si fueran cré$\operatorname{ditos}^{83}$.

\section{Justicia según la tradición judía}

La Biblia enseña que la justicia significa igualdad ante la ley. Está escrito: «No harás injusticia en el juicio; no favorecerás al pobre ni complacerás al rico, sino que con justicia juzgarás a tu prójimo ${ }^{84}$ ».

Cuando se atenta contra la vida, libertad o propiedad privada del individuo, la ley que se aplica es la Ley del Talión ${ }^{85}$. La misma

${ }^{81}$ Iosef Caro, ob. cit., p. 86.

${ }^{82}$ Ludwig von Mises, Murray N. Rothbard, Joseph Salermo, Hans-Hermann Hoppe, Jesús Huerta de Soto, Philipp Bagus, son algunos de los economistas que han defendido esta teoría. Cabe destacar que Huerta de Soto en su libro Dinero, Crédito Bancario y Ciclos Económicos expone detalladamente la violación de los principios jurídicos que suponen contratos de depósito irregular con reserva fraccionaria; asimismo, analiza en los efectos microeconómicos que genera esta violación a los principios generales del Derecho.

${ }^{83}$ Mises, en La teoría del dinero y el crédito, dice: «Si crédito en sentido económico significa cambio de bienes o servicios presentes por bienes o servicios futuros, resulta muy difícil incluir las operaciones de referencia bajo el concepto de crédito»; esto porque «el hecho de que haya depositado dinero no significa en modo alguno que renuncie a disponer inmediatamente de la utilidad que pueda procurarle». Véase Ludwig von Mises, La teoría del dinero y el crédito, Unión Editorial, 2012, p. 242.

${ }^{84}$ Antiguo Testamento, Levítico, 19:15.

85 «El que vertiere sangre de hombre, por el hombre dará su sangre vertida (Antiguo Testamento, Génesis 9:6)», «Ojo por ojo, diente por diente, mano por mano, pie por pie, quemadura por quemadura, herida por herida, moretón por moretón (Antiguo Testamento, Éxodo 21, 24:25)». Según el Mishné Torá: «tradicionalmente se interpreta que significa pagar su valor en dinero» Moisés ben Maimónides, ob. cit., 1998, p. 226. 
tiene como fin retribuir al afectado de modo proporcional al daño recibido $^{86}$.

Según la concepción de Filón de Alejandría, la justicia «es la encargada de asignar a cada uno lo que corresponde, y se ubica en un plano distinto al del acusador y al del acusado, en el de juez. Y, así como un juez no se propone vencer a nadie, ni combatir con nadie ni enfrentar a nadie sino emitir su dictamen en justa decisión, del mismo modo la justicia no es adversaria de nadie y acuerda a cada uno lo que le corresponde en derecho ${ }^{87}$ ».

El Mishné Torá asocia la justicia con la retribución del daño que se ha cometido. La misma debe considerar cinco cosas, a saber: daños, sufrimientos, curación, tiempo perdido y humillación ${ }^{88}$.

$\mathrm{Al}$ asesino se le condena con la pena de muerte; igual que al secuestrador, pues al secuestrar estaba dispuesto a matar. Al ladrón se le condena con retribuir el doble, de modo tal que termine perdiendo tanto como quiso quitarle a su semejante ${ }^{89}$.

Si el ladrón no poseyera bienes muebles, el Tribunal se apodera de sus bienes raíces y recauda todo lo mejor de ellos. Si no posee bienes raíces ni muebles, el Tribunal vende al ladrón como esclavo y entrega el dinero así obtenido al damnificado ${ }^{90}$.

En la defensa de la vida y libertad, como se ha dicho, no es sólo permitida la autodefensa, sino que es una obligación. Con respecto a la defensa de la propiedad, no es necesario recurrir a un Tribunal siempre, sino que «un hombre puede hacerse justicia por su mano, si está en condiciones de hacerlo. Siempre que proceda conforme a la ley ${ }^{91} »$. Dice el Shulján Aruj: «Si el que ha robado se resistiera, el

\footnotetext{
${ }^{86}$ La ética libertaria comparte este principio. Véase, por ejemplo Murray N. Rothbard, La Ética de la Libertad, Unión Editorial, 2009.

${ }^{87}$ Filón, Obras completas de Filón de Alejandría, Acervo Cultural, Buenos Aires, 1975, pp. 155-156, Vol. I. Dice también Filón: «tolerar que entre los delitos y los castigos no exista correspondencia, sino pertenezcan a distintas categorías unos de otros, no es dar bases firmes a la legalidad sino subvertirla». Filón, ob. cit., p. 382, Vol. IV.

${ }^{88}$ Moisés ben Maimónides, ob. cit., 1998, p. 226.

${ }^{89}$ En caso de robo de ovejas debe pagar cuatro veces el valor y en el robo de bueyes cinco veces el valor de lo robado.

90 «Si no tuviere, será vendido por su hurto». Véase Moisés ben Maimónides, ob. cit., 1998, p. 215.

91 Moisés ben Maimónides, ob. cit., 1998, p. 299.
} 
dueño puede inclusive forzarlo, si no consigue recuperar su pertenencia por otro medio ${ }^{92}$ ».

\section{Impuestos}

El primer impuesto era la Gran T'rumá o lo primero del trigo, mosto, aceite y lana ${ }^{93}$. Este impuesto consistía en entregar al menos un sesentavo de la cosecha ${ }^{94}$ para los sacerdotes.

Se debía además, pagar el diezmo de las cosechas, como ofrenda para el sustento para los de la Tribu de Leví, que servían a Dios en el Templo. Sin embargo, el israelita laico tenía derecho a conservar el primer diezmo. También existía un segundo diezmo y el diezmo para los pobres.

En Libro de los Preceptos, obra de Maimónides previa al Mishné Torá, escrita en árabe bajo el nombre Kitab al-Farayd o Libro de los preceptos divinos, se establecen las donaciones o tributos por cabeza. Estos variaban según la edad y dependiendo si se era hombre o mujer ${ }^{95}$. Estas contribuciones se daban al sacerdote o a la Administración del Templo, según los preceptos.

Los habitantes de una ciudad podían legalmente obligarse entre sí a contribuir para la construcción de una muralla, portones, y barras para la defensa de la ciudad, también para la erección de una sinagoga local y para la compra de un libro de la Torá, los libros de los Profetas y de las demás sagradas Escrituras. Lo interesante en relación a los aportes para la construcción de murallas, es que no se determinaban en función de la riqueza del contribuyente, sino que el aporte debía ser proporcional a la proximidad de cada casa a la muralla. Cuanto más cerca vivía uno, mayor debía ser su contribución ${ }^{96}$.

\footnotetext{
${ }^{92}$ Iosef Caro, ob. cit., p. 73. Vol. IV.

93 Antiguo Testamento, Deuteronomio, 18:4.

94 Moisés ben Maimónides, ob. cit., 1998, p. 161.

95 Un Shekel es 22,68 gr de plata y 1 perutá es 0,02 gramos de plata.

96 Moisés ben Maimónides, ob. cit., 1998, p. 260.
} 


\section{Sistema de gobierno ${ }^{97}$}

Parece ser que los exégetas judíos comprendían muy bien la naturaleza humana y la peligrosa inclinación al abuso del poder. Los diez mandamientos; que son los pilares de la ética judía, y sobre los cuales se edifican los demás preceptos y leyes, fueron grabados en piedra. El simbolismo "grabado en piedra» denota permanencia; y en caso de los diez mandamientos, es además de una señal de la perfección e inmutabilidad de la Ley, una protección contra la arbitrariedad de los gobernantes.

La ley judía establece la existencia de un monarca, a quien se le debía tratar con gran respeto, y guardársele temor y reverencia. El rey tenía la potestad de ejecutar a quien se le rebelaba; sin embargo, la ley le exigía ser devoto de Dios, «humilde y de corazón blando», debía comportase con «extrema humildad» y se le prohibía infundir miedo a sus vasallos para satisfacer ambiciones personales. El rey debía vivir de modo ejemplar y sin excesos. Se le prohibía tener oro y plata en demasía, sólo podía poseer el caballo que él montaba, se le prohibía embriagarse y tener muchas mujeres ${ }^{98}$.

Si una persona desatendía el mandato del rey por realizar un deber religioso, aunque fuera un deber leve, no se le castigaba; pues: «si hay que elegir entre las palabras del patrón y las del esclavo, las del patrón están primeras ${ }^{99}{ }{ }$. Asimismo, si el rey decretaba la abolición de un precepto religioso, no se le obedecía ${ }^{100}$.

El Gran Tribunal del Templo o Sanhedrei Guedolá, era un tribunal en Jerusalén con 71 integrantes; 70 de ellos eran jueces ancianos, y un Nasí o jefe de la asamblea. Ellos dictaban lo que era per-

${ }^{97}$ Santo Tomás de Aquino consideró el régimen mixto de la Sagrada Escritura como el más deseable, pues en él, la autoridad de Moisés y sus sucesores, se veía equilibrada por el Sanhedrín que fundamentaba sus sentencias en la Constitución Hebrea.

${ }_{98}$ Moisés ben Maimónides, ob. cit., 1998, pp. 322-329.

99 Moisés ben Maimónides, ob. cit., 1998, p. 323.

${ }^{100}$ En referencia a la figura de los reyes, resulta interesante la percepción que tenía Filón de Alejandría: «Y así, Homero acostumbraba a llamar a los reyes "pastores de pueblos", aunque la naturaleza con más precisión aplica este título a los buenos, como que los reyes más frecuentemente resultan ser rebaños que pastores ya que los guía el vino puro, las formas hermosas, los pasteles, los alimentos condimentados, y los deliciosos platos preparados por cocineros y reposteros; para no referirme a los apetitos que engendra el oro y la plata». Filón, ob. cit., p. 121, Vol. V. 
mitido y lo prohibido según la tradición, los sistemas de la Torá, los decretos y normas, o según su criterio en situaciones particulares.

Además, en cada ciudad existía un Sanhedrei Ketaná o pequeño tribunal, con 23 jueces. En aquellos pueblos donde la población judía no alcanzaba los 120 individuos, se debía nombrar al menos 3 jueces.

Para evitar el poder ilimitado del rey, el mismo no podía ser designado miembro del Sanhedrín. Un Sumo Sacerdote, en cambio, sí podía ser miembro del Sanhedrín.

Toda ley con adversa reacción popular, debía ser derogada y no se podía imponer por fuerza ${ }^{101}$.

\section{Guerra}

La ley judía prohíbe declarar la guerra a nadie, si no se le ha invitado primeramente a hacer las paces. Está escrito en la Biblia: "Cuando te acerques a una ciudad para conquistarla (primeramente) le ofrecerás paz $^{102}$ ». Además, cuando se pone sitio a una ciudad para conquistarla, no se rodea por los cuatro costados, sino sólo por tres; y se deja una vía de salida para que todo aquel que quiera escapar pueda hacerlo. No se cortan los árboles frutales ni se obstruye el paso de agua para el enemigo ${ }^{103}$.

Cuando se trata de una guerra opcional, sólo se puede conducir al pueblo a ella con el consentimiento del Tribunal Supremo de setenta y un miembros ${ }^{104}$.

Si los habitantes responden pacíficamente y aceptan los siete preceptos de los hijos de Noé, no se mata a ninguno, mas deben pagar tributo; que es servir al rey con sus personas y propiedades. Para el pueblo judío está prohibido defraudar el pacto con ellos, una vez hayan aceptado la paz ${ }^{105}$.

\footnotetext{
${ }_{101}$ Moisés ben Maimónides, ob. cit., 1998, p. 299.

102 Antiguo Testamento, Deuteronomio, 20:10.

103 Antiguo Testamento, Deuteronomio, 20:19.

${ }^{104}$ Moisés ben Maimónides, ob. cit., 1998, p. 324

${ }^{105}$ Moisés ben Maimónides, ob. cit., 1998, p. 325.
} 


\section{III \\ LA FILOSOFÍA \\ DE MOISÉS BEN MAIMÓNIDES}

Maimónides nace en 1135 en Córdoba, España, en el seno de una distinguida familia rabínica.

En el segundo tercio del siglo XII desaparece la tolerancia islámica en lo que hoy es España. Los almohades les quitan a los judíos sus derechos civiles y libertad. Grandes y florecientes comunidades judías se desmoronan; entre ellas, Córdoba, Granada y Lucena.

Maimónides tuvo que cambiar a menudo de residencia entre distintas ciudades de al-Ándalus, hasta que finalmente en 1160 sale de España hacia Marruecos y de ahí a Israel; pero al ver la decadencia espiritual, se traslada a Egipto, sabiendo que trasgredía la ley que prohibía el retorno a esa tierra donde el pueblo judío fue esclavo.

En Egipto se convierte en un erudito líder religioso, filósofo y eminente médico. En sus diversos escritos que comprendieron: derecho judaico, moral, filosofía y medicina, Maimónides incorpora explicaciones racionales que concilian la fe con la filosofía.

A lo largo de su vida, Maimónides escribe numerosas obras; entre ellas, un comentario sobre la Mishná, el Mishné Torá, Guía de los Descarriados, varios tratados médicos, filosóficos y epístolas.

Después de su muerte en 1204 en Fosfat, Egipto, la obra de Maimónides se esparció por España e influyó en numerosos pensadores, principalmente en los escolásticos. Santo Tomás de Aquino, quien cita muy frecuentemente su obra, le llamó: «Moisés el egipcio».

En el mundo cristiano fue tal vez el pensador más conocido influyendo en los escolásticos Guillermo de Auvernia, Alejandro de Hales, Siger de Brabante, San Alberto Magno y Santo Tomás de Aquino, todos los cuales le mencionan frecuentemente y discuten sus doctrinas metafísicas... ${ }^{106}$.

${ }^{106}$ Joaquín Lomba, Maimónides y el pensamiento medieval, Servicio de Publicaciones Universidad de Córdoba, 2007, p. 53. 
Hoy, más de ochocientos años después de su muerte, el judaísmo se sigue refiriendo a él cómo el mayor líder y pensador que haya existido en la historia post-bíblica. Por eso el proverbio: «De Moisés a Moisés, no hubo otro Moisés».

\section{Filosofía moral de Maimónides}

A pesar de haber sido aristotélico en la mayor parte de su filosofía, Maimónides tuvo importantes diferencias con respecto a la moral de Aristóteles, quien consideraba que la misma era absoluta y debía ser elaborada deliberadamente por los gobernantes.

El filósofo cordobés consideraba que las pautas morales no pueden ser dadas por principios lógicos ni por dictámenes de la sociedad, sino que es la «Ley Perfecta» aquella que conduce al hombre a la integridad moral: «La Ley Perfecta es la que nos perfecciona». Esta ley, que proviene de las enseñanzas de la Torá de Moisés, y de los profetas, determina el término medio verdadero.

Cabe comentar que Maimónides sigue la concepción que Filón de Alejandría, había expuesto un milenio antes. El alejandrino distinguió la Ley, que emana del recto orden de la naturaleza, de los mandatos que redacta el legislador ${ }^{107}$.

107 Filón había desarrollado la idea que la «Divina ley» existía antes del hombre ciudadano, y era ésta la que asignaba «a cada cosa lo que le convenía y correspondía». «143. L. Ahora bien, puesto que todo estado bien regido se ajusta a una constitución, era necesario que el ciudadano del mundo se rigiese por la constitución por la que se rige el mundo entero. Y esta constitución es el recto orden de la naturaleza, llamada con más propiedad "sagrada norma", pues se trata de una Divina ley, conforme con la cual fue asignado a cada cosa lo que le convenía y correspondía. Preciso era que en este estado y bajo esta constitución existieran antes del hombre ciudadanos, a los que con justicia podría calificarse de ciudadanos del Gran Estado, ya que les cupo como residencia el más dilatado de los ámbitos, y fueron inscriptos en el padrón del más grande y perfecto de los estados». Filón, ob. cit., p. 117, Vol. III.

El pensamiento de Filón dedujo la existencia de un «orden natural». Buscó integrar la concepción de kosmos de los griegos, con la concepción teocéntrica judía de la «Divina ley», o «Ley perfecta» de la que Maimónides hablaría un milenio después. Cicerón, refiriéndose al sistema jurídico romano, había presentado la concepción de la idea evolucionista del orden espontáneo: «no se instituyó en una generación, sino durante un largo período de varios siglos y muchas generaciones de hombres. Porque nunca ha existido un hombre tan inteligente como para preverlo todo; e incluso aun- 
La filosofía moral de Maimónides es producto de la fe en Dios, asumiendo así un carácter eterno. Como menciona el Mishné Torá: «Las leyes y estatutos de esta Torá son invariables para siempre jamás; no se les debe añadir ni quitar nada ${ }^{108}$.

Desde esta perspectiva, Maimónides comprende la existencia de algunos principios inmutables que protegen la integridad moral del hombre y la supervivencia de la especie. Y es que así como los mandamientos grabados en piedra contienen principios inamovibles, Maimónides manifiesta que la «Ley Perfecta» es una guía inalterable para el buen orden social, producto de la sabiduría divina.

En cuanto a la función de los preceptos, Maimónides adopta una postura utilitarista, manifestando que ni siquiera los preceptos «del hombre para con Dios» carecen de utilidad para la sociedad; sino que: «Todo precepto, tanto si pertenece al grupo "harás" como si ordena "no harás", tiene un único fin: enseñar buenos modales, inculcar nobles sentimientos y aumentar el caudal de conocimientos... Y aunque se llame "del hombre para con Dios", lo cierto es que trae provecho en las relaciones "del hombre para con su prójimo a través de medios indirectos».

Desarrollando esta postura utilitarista sobre los preceptos, indica que aquellos estatutos cuya razón nos es desconocida «no tienen otra finalidad que la de alejarnos de la idolatría», pues la idolatría impide «al espíritu humano investigar las concepciones del intelecto o las acciones útiles». Agrega además: «En efecto, todas las virtudes morales sólo conciernen a las relaciones de los hombres entre ellos. La perfección moral que posee un hombre, en cierto modo no hace sino disponerlo para ser útil a los demás, de manera que se torne con ello en un instrumento que sirva a los otros ${ }^{109}{ }^{\text {». }}$.

Como se expondrá en detalle más adelante, el fundamento de la filosofía moral de Maimónides es la absoluta libertad del individuo de elegir entre el bien y el mal, el don del libre albedrío. Como

que pudiéramos concentrar todos los cerebros en la cabeza de un mismo hombre, le sería a este tener en cuenta todo al mismo tiempo, sin haber acumulado la experiencia que se deriva de la práctica ejercida a lo largo del transcurso de un largo período de la historia». Jesús Huerta de Soto, ob. cit., p. 159.

${ }^{108}$ Moisés ben Maimónides, ob. cit., 1998, p. 327.

109 Moisés ben Maimónides, ob. cit., 1977, p. 316, Vol. III. 
menciona en Guía de los Perplejos: «El pilar de la Ley de Moisés y de todos los que le sucedieron es el libre albedrío del hombre».

Importantes pensadores la Escuela Austriaca de Economía, hacen una distinción entre la «Ley en el sentido material» y los mandatos. La Ley se refiere al marco de normas generales y abstractas, que hacen posible el proceso de cooperación social, y que han surgido y evolucionado espontáneamente. Los mandatos, en cambio, son reglamentos de tipo administrativo impuestos coactivamente por el órgano director ${ }^{110}$. Su postura defiende la existencia de un Derecho Natural de contenido variable, o bien un «Derecho Natural Evolutivo de contenido fundamental, de carácter formal, y mínimo en su contenido (a modo de Principios Esenciales), que deberá ir depurándose y adquiriendo contenido en cada momento histórico, de forma lenta, cautelosa y prudente a lo largo del tiempo $\mathrm{y}$, a su vez, cumpliendo una labor informadora y de guía para el conjunto del derecho ${ }^{111}$ ».

\section{Racionalismo}

Si hay algo que caracteriza al pensamiento de Maimónides, es su racionalismo. Un racionalismo, que como detallaremos, reconoce los límites de la comprensión humana. Maimónides niega que la mente y entendimiento estén en la jurisdicción de Dios; asimismo, los actos humanos dependen del hombre únicamente.

110 Jesús Huerta de Soto, Socialismo, Cálculo Económico y Función Empresarial, obra citada, pp. 126-127.

${ }^{111}$ César Martínez Meseguer, Teoría evolutiva de las instituciones, Unión Editorial, 2015, p. 121. La postura austriaca ortodoxa, presentada por Menger y desarrollada extensamente por Hayek, apunta en esta dirección histórico-evolutiva; sin embargo, es importante señalar que una rama importante de esta escuela, liderada por Murray $\mathrm{N}$. Rothbard, defiende una postura más estática de la «ley natural» a la que se puede llegar con el uso de «la recta razón». Esta concepción tomista de la ley natural, según Rothbard: «descansa sobre la idea de que vivimos en un mundo compuesto por más de una entidad - en realidad, por un vasto número de entidades-, y que cada una tiene propiedades distintas y específicas, una «naturaleza» diferente, que puede ser investigada por la razón del hombre, por su sentido de la percepción y por sus facultades mentales». Véase Murray N. Rothbard, ob. cit. 2015, p. 44. 
Según Maimónides, la existencia de Dios es una construcción intelectual lógicamente argumentada. Santo Tomás de Aquino, discípulo intelectual de las enseñanzas de Maimónides, un siglo después argumentaría el mismo principio ${ }^{112}$.

Contrario a la filosofía griega que ve al hombre como sólo una criatura más perfecta entre los demás seres vivos, la perspectiva judía, a la cual acude Maimónides, ve al hombre como esencialmente distinto, pues se diferencia por poseer «imagen y semejanza divina», que según Maimónides es justamente su capacidad de razonar.

El racionalismo de Maimónides queda claramente plasmado en la siguiente cita: «Sólo después de haber comprendido a Dios y sus obras, en cuanto lo exige la inteligencia, puedes consagrarte enteramente a Él, buscar acercarte a Él y afirmar el lazo que existe entre ti y Él, es decir, el intelecto ${ }^{113}$ ».

Maimónides traslada su racionalismo a los tiempos mesiánicos: «Nadie vaya a suponer que en los tiempos mesiánicos desaparezca ninguna de las leyes de la naturaleza o se produzca una modificación de lo hecho en el Génesis. No, sino que el mundo seguirá con sus leyes inmutables... ${ }^{114}{ }^{\prime}$.

\section{Límites de la razón humana}

La doctrina aristotélica no le reconoce límites al intelecto humano, pues la mente humana podría captar absolutamente todo. Maimónides, en cambio, reconoce que existen fenómenos que no pueden ser comprendidos por el intelecto, sino que deben de abordarse por medio de la profecía.

Maimónides escribe a Rabí Jisdai Haleví: «Dios sabe que existe algo superior al conocimiento humano tal cual lo suponen los filósofos, y es la profecía. La profecía constituye otro mundo en el

112 Schumpeter, en su obra Historia del análisis económico, omite la influencia que pudo haber tenido Maimónides en el racionalismo del Aquinate, y la noción de que existe conocimiento imposible de alcanzar por medio de la razón, que sólo puede ser alcanzado por la revelación.

${ }^{113}$ Moisés ben Maimónides, ob. cit., 1977, p. 299, Vol. III.

114 Moisés ben Maimónides, ob. cit., 1998, p. 327. 
que no cabe la discusión, a la que están tan acostumbrados los filósofos».

En Guía de los Perplejos expone muy claramente la idea con estas palabras: «has de saber que el intelecto humano conoce fronteras, que se ajustan a su capacidad y poder de asimilación, y hay cosas que no puede comprender bajo ningún concepto, y las puertas del entendimiento están cerradas para él ${ }^{115}$ ».

Maimónides instruye que el nivel más alto de perfección humana se logra: «si eres capaz de dudar y no tratar de convencerte de que existen pruebas con que sostener lo que no puede ser demostrado, ni intentas percibir cosas que están más allá de tus alcances $^{116}$ ».

Este racionalismo de tipo moderado que exhibe Maimónides, caracteriza al pensamiento de la Escuela Austriaca. Friedrich A. Hayek despliega extensamente en su obra El Orden Sensorial una noción muy similar, en la que propone el principio de que el hombre es incapaz de comprender con su razón órdenes superiores ni de la misma clase. En sus palabras: «Si esto es así, quiere decirse que ningún agente explicativo puede nunca explicar objetos de su misma clase, o de su mismo grado de complejidad, y que por tanto, el cerebro humano nunca podrá explicar completamente sus propias operaciones ${ }^{117}$ ».

\section{Libre albedrío}

En contra del pensamiento aristotélico, que negaba iniciativa propia del hombre, viéndolo como un juguete del azar o del «caprichos de los dioses». La doctrina moral de Maimónides, fundamentada en la tradición del pensamiento judío, fue «emancipadora». Liberaba al hombre de la subordinación al destino y fomentaba la responsabilidad individual.

${ }^{115}$ Moisés ben Maimónides, ob. cit., 1977, Vol. I.

${ }^{116}$ Moisés ben Maimónides, Guía de los perplejos o descarriados, Ediciones Obelisco, Barcelona, 2011, p. 47.

117 F.A. Hayek, El orden sensorial, Unión Editorial, Madrid, 2011, p. 307. 
Todo hombre goza de libre albedrío: si quiere inclinarse por el buen camino y ser un hombre justo, es libre para ello; si quiere inclinarse por el mal camino y ser un malvado, es libre para ello. Esto es lo que está escrito en la Torá: «He aquí que el hombre ha venido a ser como uno de nosotros para conocer el bien y el mal (Génesis 3:22)». Es decir: He aquí que la especie humana es única en el mundo, sin que haya otra especie que se le parezca en este sentido: que el hombre, por sí mismo, por su entendimiento y pensamiento, conoce el bien y el mal y hace todo lo que desea, sin que nadie le impida hacer el bien o el mal, y sólo por eso pudo Dios agregar: «Quizá extienda su mano y tome también del árbol de la vida $^{118}{ }$.

Señalando la contrariedad del determinismo con los preceptos judíos, expresa:

¿Cómo podría Dios habernos ordenado por medio de profetas: Haz esto y no hagas esto otro, corregid vuestros caminos y no marchéis tras vuestra maldad?, si ya Él ha decretado lo que ha de ser cada hombre en el momento de crearlo, o bien si su esencia innata ha de arrastrarlo a cosas de las cuales es imposible apartarse, ¿Qué lugar habría entonces para la Torá toda? ${ }^{119}$.

La filosofía de la Escuela Austriaca, y en particular la posición que expone Ludwig von Mises con respecto al libre albedrío sigue la misma vía argumental Maimónides. Mises señala que es cierto que «todo lo que sucede es consecuencia del estado de las cosas precedente»; sin embargo, en última instancia «el hombre elige entre formas alternativas de conducta ${ }^{120} \gg$. De un modo muy similar a la crítica de Maimónides al determinismo, Mises se pregunta: «Por qué preocuparse si todo debe terminar como está preordenado ${ }^{121}{ }$, e ironizando sobre la incompatibilidad del determinismo con las nociones metafísicas de culpa, pecado y retribución, insiste: «iQué soberbia pretensión es castigar a un hombre que simplemente hizo lo que han determinado las leyes eternas del universo! ${ }^{122 "}$.

\footnotetext{
118 Moisés ben Maimónides, ob. cit., 1998, p. 41.

119 Moisés ben Maimónides, ob. cit., 1998, p. 42.

${ }^{120}$ Ludwig von Mises, Teoría e Historia, Unión Editorial, Madrid, 2010, p. 121.

${ }^{121}$ Ludwig von Mises, ob. cit., 2010, p. 122.

${ }^{122}$ Ludwig von Mises, ob. cit., 2010, p. 125.
} 


\section{Una perspectiva sobre la acción humana, medios,fines y utilidad}

En Guía de los Perplejos, Maimónides se refiere a las acciones humanas de un modo que no podría considerarse menos que proto-austriaco. Clasifica a las acciones en cuatro grupos: Acción vana, acción indeterminada, acción intrascendente y acción útil o buena ${ }^{123}$.

La acción vana, es según Maimónides una acción que no alcanza su objetivo o fin; o sea, lo que los economistas austriacos denominarían posteriormente un «error empresarial». La acción indeterminada es la que carece de propósito; o sea, un acto instintivo que los pensadores austriacos no considerarían acción humana por carecer de una intención consciente y deliberada por parte del actor. La acción intrascendente es aquella que tiene en vista un fin insignificante. Pero aquí, Maimónides, reconociendo la utilidad subjetiva de los medios, dice: «A veces la calidad de la acción depende de quién la ejecuta; porque muchas cosas son útiles a juicio de una persona y superfluas a juicio de otras». Finalmente, «son útiles o buenas, las acciones que sirven a un propósito y lo alcan$z^{2} n^{124} \gg$. Desde la óptica austriaca, estás últimas serían aquellos medios que logran su fin; o bien, permiten al actor conseguir un fin subjetivamente valioso.

${ }^{123}$ Antes que Maimónides, el filósofo zaragozano musulmán, Ibn Bayya ya se había referido expresamente al concepto de la acción humana. Maimónides en una carta dirigida a su amigo Samuel Ibn Tibbon, manifiesta que Ibn Bayya «fue un gran filósofo; sus palabras y sus escritos son todos correctos para el que entiende y rectos para los que procuran conocimiento». Cabe destacar que su postura establece la existencia de la libertad como condición sine qua non para la ejecución de la acción humana; así lo expresa en El Régimen Solitario: «Todos los actos que pertenecen al hombre por naturaleza y que le son característicos son (los que lleva a cabo) con libertad y ninguna acción del hombre hecha con libertad se encuentra en las demás especies de cuerpos. Así pues, las acciones propiamente humanas son las hechas con libertad y todo lo que realiza el hombre con libertad es acción humana, siendo acción humana la que se lleva a cabo con libertad. Y entiendo por libertad, la voluntad que nace de la reflexión». Véase Joaquín Lomba, Algunos aspectos de la relación entre Maimónides e Ibn Bayya, Revista española de filosofía medieval, 2005, pp. 23-34.

${ }^{124}$ Moisés ben Maimónides, ob. cit., 2011, p. 256. 


\section{La paradoja del valor}

\section{Maimónides intenta explicar la paradoja del valor, asociando co- rrectamente la escasez del bien con su valor; esbozando así el con- cepto de utilidad marginal ${ }^{125}$.}

En efecto, en medida que una cosa es más necesaria al animal, se la encuentra más frecuentemente y es de precio más vil; y a medida que una cosa es menos necesaria, se la encuentra menos y es muy cara... Lo mismo ocurre con los diversos alimentos: aquellos que son más necesarios se encuentran más fácilmente, y a más vil precio, en un mismo lugar, que aquellos que son menos necesarios ${ }^{126}$.

${ }^{125}$ Las reflexiones de Maimónides se encuentran desarrolladas de modo casi idéntico y más completo en un pasaje del libro Los deberes de los corazones de Bahya Ibn Paquda, filósofo judío zaragozano de la segunda mitad del siglo XI. Evidentemente, Maimónides leyó lo escrito por Ibn Paquda y lo incorporó a Guía de los Descarriados. Las perspectivas que desarrolla Ibn Paquda, implican nociones económicas trascendentales. Comprende a la perfección que la institución de la moneda fue adoptaba de modo voluntario por el hombre; esto es, sin imposición de una autoridad. Además resalta que las necesidades humanas no se satisfacen directamente por medio de los metales, y sostiene que si fuesen abundantes no serían utilizados como medios de intercambio, pues «no tendrían ningún valor». Desarrolla además de modo extenso y completo, la relación entre escasez y valor. A continuación, la cita del brillante desarrollo de Ibn Paquda: «Es preciso, hermano mío, que reflexiones y comprendas los vestigios de la sabiduría suprema y de la suma providencia del Creador que hay en el hecho de que los hombres hayan decidido por mutuo acuerdo el poder comprar y vender a base de oro y plata y el que, en consecuencia, se esfuercen por acumularlos, contando con la benevolencia de Dios, para que con estos dos metales mejore su situación material. Y, sin embargo, ciertamente, las necesidades humanas no se cubren directamente con estos metales en sí mismos considerados. Pues si a alguien le alcanza el dolor del hambre y la sed porque carece por completo de alimentos y agua, estos metales no le sirven de nada ni se satisface con ellos en absoluto. Del mismo modo, si a alguien le duele algún miembro, no sanará con sólo la plata o el oro, pues aunque ciertas curaciones se llevan a cabo, muchas veces, utilizando otros minerales, son pocos los tratamientos que se hacen a base de plata y oro. Por esta razón observarás que estos metales preciosos los poseen en abundancia algunos hombres, pero, en cambio, son escasos para la mayoría de la gente, pues, si estuvieran al alcance de todo el mundo, no tendrían ningún valor («no los podrían usar como medio para obtener lo que ellos desean» —en traducción hebrea). Así, son escasos bajo un aspecto y abundantes bajo otro. Por consiguiente, estos metales son preciosos en un sentido y viles en otro, ya que en su misma esencia no tienen ninguna utilidad. Todo esto se debe al supremo gobierno de la sabiduría divina sobre los hombres». Véase Bahya Ibn Paquda, Los deberes de los corazones, Fundación Universitaria Española, Madrid, 1994, pp. 83-84.

${ }^{126}$ Moisés ben Maimónides, ob. cit., 1977, p. 51, Vol. I. 
Maimónides expone a continuación que la riqueza es subjetiva y que la desigualdad no implica injusticia ni violencia. En sus palabras:

Pero, que uno posea muchas bolsas de almizcle y ropas ornadas de oro mientras que otro carezca de estas cosas superfluas, no implica injusticia ni violencia. El que ha obtenido lo superfluo no ha conquistado por ello ninguna prerrogativa en su sustancia y sólo posee una ilusión engañosa o un juguete. El que carece de lo superfluo no está necesariamente disminuido en su valor: «al que había recogido mucho no le sobraba, ni faltaba al que había recogido poco; cada uno recogía conforme a lo que podía comer» (Éxodo, XVI, 18$)^{127}$.

Jesús Huerta de Soto, pensador contemporáneo de la Escuela Austriaca, atribuye a Diego de Covarrubias y Leiva la exposición de la esencia de la teoría subjetiva del valor ${ }^{128}$; sin embargo, esta noción es también desarrollada con cinco siglos de anterioridad por el judío zaragozano Bahya Ibn Paquda y expuesta posteriormente por el judío cordobés Maimónides ${ }^{129}$, que como hemos señalado fue estudiado por San Alberto Magno, El Aquinate y otros importantes pensadores medievales.

Es importante señalar que Bahya Ibn Paquda ya deducía que la escasez era condición para que el dinero tuviera valor; aprendizaje que siglos después los escolásticos españoles desarrollarían, al observar el proceso inflacionario derivado del ingreso de metales preciosos a España provenientes de América.

${ }_{127}$ Maimónides, ob. cit., 1977, p. 52, Vol. III.

${ }^{128}$ Véase Jesús Huerta de Soto, La escuela austriaca, mercado y creatividad empresarial, Editorial Síntesis, Madrid, 2012, pp. 55-56.

${ }_{129}$ Como bien expone Enrique Ghersi en su artículo Orígenes del Liberalismo, aunque obvia que en gran medida lo expuesto por Maimónides es tomado de la filosofía de Bahya Ibn Paquda. 


\section{Individualismo en la tradición judía y en la filosofía de Maimónides}

A diferencia de la filosofía griega, que centraba sus análisis en torno a la polis, considerando al individuo sólo como una parte de la misma y no como un ente teleológicamente único ${ }^{130}$; la tradición judía, y en particular la filosofía de Maimónides, asigna a la sociedad una función constructiva y necesaria para la organización política, mas niega su existencia como fin por sí misma.

El núcleo principal de la vida humana está ocupado por el hombre como individuo, y el hogar (familia) es la unidad fundamental del Estado. La función de la sociedad, es entonces ayudar al individuo a la consecución de su integridad espiritual, moral, personal y material.

Maimónides enseña que la cooperación social redunda en beneficio de todo el grupo y, en consecuencia, en el beneficio individual de quienes la practican.

La concepción moral de la sociedad judía, es la igualdad ante la ley por la sola condición humana. La perspectiva griega, con Aristóteles y sus predecesores Platón y Sócrates, consideraba la desigualdad entre clases humanas (castas) como lógica y absolutamente necesaria. Así lo justifica Aristóteles: «Algunos seres, desde el momento en que nacen, están destinados, unos a obedecer, unos a mandar; aunque en grados muy diversos en ambos $\operatorname{casos}^{131}{ }^{1}$.

Cabe señalar que la sociedad moralmente perfecta, según Maimónides, depende de la educación y comportamiento de sus integrantes, a nivel individual. Los valores de justicia y rectitud, no se transmiten de la sociedad al individuo, sino que los mismos tienen su origen en la vida privada de cada individuo y de ahí ascienden hacia la cima de la pirámide social.

Aun así, Maimónides reconoce que esta conducta ético-moral no se puede lograr espontáneamente, y justamente la función principal de la Torá es acrecentar el conocimiento y sabiduría, para

130 «No puede ponerse en duda que el Estado está naturalmente sobre la familia y sobre cada individuo, porque el todo es necesariamente superior a la parte...» Aristóteles, Política, Editorial Austral, Barcelona, 2015, p. 40.

${ }^{131}$ Aristóteles, ob. cit., p. 43. 
guiar al hombre por la senda de comportamiento correcto. Esta noción, que no deja de reconocer la influencia que ejerce la sociedad sobre el individuo, insiste en el elemento del libre albedrío, al responsabilizar al individuo por el comportamiento moral de la «sociedad» y no a la «sociedad» por el comportamiento moral del individuo.

Bruno Bauer, filósofo e historiador alemán del siglo XIX, discípulo de Hegel y mentor de Carl Marx, despreció la obra de Maimónides y recriminó la concepción individualista de los preceptos judíos, arguyendo que «el cristiano lucha y combate con un objeto que en sí es la humanidad en su conjunto», mientras que los preceptos judíos están dirigidos a «sólo una suma de individuos ató$\operatorname{micos}^{132} \gg$.

Schumpeter se refiere a la civilización subjetiva de este modo:

...Entendemos por civilización subjetiva una civilización que presenta características opuestas; una civilización en la cual la sociedad está al servicio del individuo, o sea, una sociedad que se basa en los gustos subjetivos, los satisface y permite a cada cual construirse su propio sistema de valores culturales. No necesitamos discutir la cuestión general del estatuto analítico de esos esquemas. Pero sí que nos interesa la afirmación general y muy frecuente de que la civilización medieval era objetiva y la moderna es (o lo era hasta hace poco) subjetiva o individual...133

Si concebimos la filosofía de Maimónides como una plasmación de ese subjetivismo e individualismo que le atribuye Schumpeter a la «civilización subjetiva», es razonable asociar la tradición judía a la formación del sistema capitalista y la civilización moderna.

\section{La sociedad humana según Maimónides}

Maimónides, adoptando una postura aristotélica, enseña que los humanos son seres sociables y su supervivencia depende de la cooperación humana.

${ }^{132}$ Carlos Marx, ob. cit., p. 97.

${ }^{133}$ Joseph A. Schumpeter, ob. cit., p. 117. 
... si se supusiera un individuo humano que existiera solo, privado de todo régimen e igualado a los animales, (ese individuo) perecería al momento, y no podría durar un solo día, como no fuera por accidente, quiero decir, que encontrase casualmente algo para alimentarse $^{134}$.

Maimónides expresa que la perfección del cuerpo, que se podría entender como bienestar material, es requisito para la perfección del alma, que es la perfección última. Manifiesta que la perfección del cuerpo solo se consigue mediante la cooperación social $^{135}$.

Ludwig von Mises, al referirse a la acción humana y la cooperación social, adopta una perspectiva similar ${ }^{136}$. Comprende que la eliminación de los malestares materiales no está contrapuesta a la mejora espiritual; sino que todo lo contrario, es un requisito para alcanzar fines más sublimes.

IV

\section{CONCLUSIONES}

Muy influyentes pensadores que han estudiado la historia del pensamiento económico, han dado un tratamiento contrapuesto a la herencia filosófica y moral judía. Unos la han considerado la fuente del método individualista y subjetivista, y origen del capitalismo; mientras que otros han omitido su influencia histórica. Asimismo, el impacto que la filosofía moral judía pudo haber tenido sobre los escolásticos de Salamanca, a través principalmente de los escritos de Maimónides, es un tema que no ha sido debidamente investigado hasta el momento.

\footnotetext{
134 Moisés ben Maimónides, ob. cit., 1977, p. 232, Vol. I.

135 Moisés ben Maimónides, ob. cit., 1977, p. 141, Vol. III.

136 «La teoría de la división del trabajo -punto de partida de la sociología-demuestra que no existen conflictos como sostiene la metafísica socialista, entre los intereses de la sociedad y los del individuo. El individuo aislado no puede alcanzar sus fines, sean los que fueren, o por lo menos no lo puede en la medida de la cooperación social». Ludwig von Mises, Problemas epistemológicos de la economía, Unión Editorial, Madrid, 2013, p. 86.
} 
Respecto a la ética económica presente la tradición judía, es destacable la defensa históricamente consistente de la propiedad privada y el laissez-faire. De igual modo, en los tratados legales, la concepción del trabajo como fuente de apropiación original de los bienes, el derecho a la autodefensa y el principio de no agresión, son fundamentos que aproximan a la tradición judía con los principios libertarios.

La tradición judía, desde tiempos bíblicos enseña que el hombre es responsable de su vida y sustento. La caridad; sin embargo, es considerada el precepto más importante, y consiste en un mecanismo de auténtica solidaridad y filantropía, pues no media en ella amenaza de coacción.

Como parte del estudio de la historia del pensamiento económico, en lo que se refiere a la usura, los subterfugios que surgieron en las discusiones rabínicas para evadirla sin infringir la ley, merecen ser considerados. De igual modo, es de particular interés para la Escuela Austriaca de Economía, el estudio histórico del tratamiento que le han dado los filósofos y exégetas judíos a los préstamos y depósitos. En particular el tratamiento que hizo al respecto Filón de Alejandría y las discusiones rabínicas presentes en el Talmud.

El pueblo judío tuvo históricamente un sistema de gobierno mixto, con un rey con poderes limitados y un órgano judicial compuesto por el Sanhedrín. El sistema legal estaba basado en la ley mosaica y en las discusiones talmúdicas, que a su vez fueron semilla de ulteriores tratados como el Mishné Torá y el Shulján Aruj.

Bahya Ibn Paquda, filósofo judío zaragozano del siglo XI, intentando explicar la paradoja del valor, asoció correctamente la escasez del bien con su valor; esbozando así el concepto de utilidad marginal. Maimónides incorporó la sabiduría de Ibn Paquda en su Magnum Opus: Guía de los Descarriados.

El aparente vacío entre el pensamiento económico de la tradición judía y las doctrinas de la Escuela de Salamanca, podría ser explicado por el tratamiento, en unas ocasiones nulo, y en otras insuficiente, de las doctrinas de Moisés ben Maimónides. Estas, marcadas por su racionalismo característico, presentaron la concepción individualista y subjetivista de la tradición que heredó, y fueron fuentes de la que bebieron los más importantes pensadores cristianos de la Edad Media; en especial, Santo Tomás de Aquino. 


\section{REFERENCIAS BIBLIOGRÁFICAS}

La Biblia (Vol. 1). (1991). Tel-Aviv, Sinai.

La Biblia (Vol. 2). (1991). Tel Aviv, Sinai.

Aristóteles. (2015). Política. Barcelona, Austral.

BÖHM-BAWERK, E. (2009). Valor, capital, interés. Madrid, Unión Editorial.

Caro, I. (1979). Kitzur Shulján Aruj. Buenos Aires, Editorial Yehuda.

FILÓn. (1975). Obras completas de Filón de Alejandría (Vol. IV). Buenos Aires, Acervo Editorial.

- (1975). Obras completas de Filón de Alejandría (Vol. I). Buenos Aires, Acervo Cultural.

- (1975). Obras completas de Filón de Alejandría (Vol. III). Buenos Aires, Acervo Editorial.

- (1975). Obras completas de Filón de Alejandría (Vol. II). Buenos Aires, Acervo Editorial.

- (1975). Obras completas de Filón de Alejandría (Vol. V). Buenos Aires, Acervo Editorial.

- (2010). Obras Completas Filón de Alejandría (Vol. II). Madrid, Editorial Trotta.

Friedman, M. (s.f.). Foundation for Economic Education. Recuperado el 16 de junio de 2016, de www.fee.org: https://fee.org/articles/ capitalism-and-the-jews/

GHERSI, E. (Enero de 2006). www3.upc.edu.pe. Recuperado el 15 de abril de 2016, de http://www3.upc.edu.pe/sociedadlibre/Det Bol1.asp?CON=2284\&BOL=18\&EJE $=211 \& S E C=O$ pini $\%$ F3n

Grice-Hutchinson, M. (1990). Aproximación al pensamiento económico en Andalucía: de Séneca a finales del siglo XVIII. Málaga, Librería Ágora, S.A.

- (1995). Ensayos sobre el pensamiento económico en España. Madrid, Alianza Editorial.

HAYEK, F.A. (2010). La fatal arrogancia. Madrid, Unión Editorial.

- (2011). El orden sensorial. Madrid, Unión Editorial.

HuerTA DE SOTO, J. (2012). La escuela austriaca, mercado y creatividad empresarial. Madrid, Síntesis.

- (2010). Socialismo, cálculo económico y función empresarial. Madrid, Unión Editorial. 
LomBA, J. (2005). «Algunos aspectos de la relación entre Maimónides e Ibn Bayya». Revista Española de Filosofía Medieval, pp. 23-34. - (2007). Maimónides y el pensamiento medieval. (J. L. Alonso, Ed.) Córdoba, Servicio de Publicaciones Universidad de Córdoba.

Maimónides, M. (1977). Guía de los descarriados (Vol. I). Buenos Aires, Editorial S. Sigal.

- (1977). Guía de los descarriados (Vol. II). Buenos Aires, S. Sigal.

- (1977). Guía de los descarriados (Vol. III). Buenos Aires, S. Sigal.

- (1998). Mishné Torá. Tel-Aviv, Sinai.

- (2006). Obras filosóficas y morales de Maimónides. Barcelona, Ediciones Obelisco.

- (2011). Guía de los perplejos o descarriados. Barcelona, Ediciones Obelisco.

MArx, C. (1969). La cuestión judía. Buenos Aires, Coyoacán.

Matus, M. (Diciembre de 2013). «Trayectoria de la usura y el lucro en el judaísmo». Cuadernos Judaicos, pp. 100-121.

Martínez, C. (2015). La teoría evolutiva de las instituciones. Madrid, Unión Editorial.

Mises, L. (1944). Omnipotent government. Connecticut, Yale University Press.

- (2010). Teoría e historia. Madrid, Unión Editorial.

- (2012). La teoría del dinero y el crédito. Madrid, Unión Editorial.

- (2013). Problemas epistemológicos de la economía. Madrid, Unión Editorial.

- (2015). La acción humana. Madrid, Unión Editorial.

Netanyahu, B. (2004). Don Isaac Abravanel, estadista y filósofo. Salamanca, Europa.

Orian, M. (2004). Maimónides: Vida, pensamiento y obra. Madrid, Riopiedras Ediciones.

Paquda, B. I. (1994). Los deberes de los corazones. Madrid, Fundación Universitaria Española.

PerednIK, G. (2006). Notables pensadores judíos en la civilización occidental. Uruguay, ORT.

Rothbard, M. N. (2015). Hacia una nueva libertad. Madrid, Unión Editorial.

- (2015). Historia del pensamiento económico. Madrid, Unión Editorial. 
SCHUMPETER, J. (2004). Historia del análisis económico. Barcelona, Ariel S.A.

SOMBART, W. (1972). El burgués. Madrid, Alianza Editorial.

- (2001). The jews and modern capitalism. Ontario, Batoche Books Limited.

WeIss, A. J. (Ed.). (1964). El Talmud de Babilonia - Tratado Baba Metzía. Buenos Aires, Acervo Cultural.

- (Ed.). (1966). El Talmud de Babilonia - Tratado Baba Batrá. Buenos Aires, Acervo Cultural.

- (Ed.). (1966). El Talmud de Babilonia - Tratado Kidushim. Buenos Aires, Acervo Cultural.

- (Ed.). (1971). El Talmud de Babilonia - Tratado Sabat. Buenos Aires, Acervo Cultural. 